\title{
Engineering Degree Trends for African American Women and Men
}

\section{Prof. Keith J Bowman, Illinois Institute of Technology}

Keith J. Bowman became Professor and Chair of the Department of Mechanical, Materials and Aerospace Engineering at Illinois Institute of Technology (IIT) in August, 2011, immediately following nearly five years of experience leading the Purdue School of Materials Engineering as Interim Head and Head. His first faculty appointment was as an Assistant Professor at Purdue University in 1988 after receiving degrees from Case Western Reserve University (CWRU), (B.S. 1981, M.S. 1983) and the University of Michigan (Ph.D. 1987). He was promoted to Associate Professor in 1992, and then promoted to Professor in 1996. Keith Bowman served as a visiting professor and received Alexander von Humboldt stipends for research at the Technical University of Darmstadt, Germany in 1996 and again in 2002. He served as a visiting professor at the University of New South Wales in Sydney, Australia in 2003. From 1996 to 2004 he served as graduate program chair of the Purdue School of Materials Engineering (MSE) during a substantial retooling of the program to more strongly emphasize doctoral degrees. In 2005-06 he served a one-year appointment as Interim Head of MSE and in 2007 was named Head of the Purdue School of Materials Engineering (MSE). He was named a Fellow of the American Ceramic Society in 2000, and has held several division and society positions, including becoming a member of the Board of Directors in 2012. In ASME, known as the American Society of Mechanical Engineers, he is a member of the executive committee of the mechanical engineering department heads and chairs (MEDHC). Awards at Purdue University include receiving the MSE Best Teaching Award in 1992 and 1995 and Purdue's highest teaching award, the Charles Murphy Undergraduate Teaching Award in 1995. In 2003 Professor Bowman's name was added to the Purdue Book of Great Teachers. In 2007 he received the Purdue College of Engineering Mentoring Award and he became a Professor of Engineering Education (by courtesy). In 2012 he was invested as the first Duchossois Leadership Professor in the IIT Armour College of Engineering. 
Engineering Degree Trends for African American Women and Men

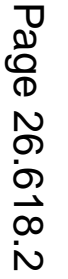


As of this past year, individuals self-identifying as African American were $13 \%$ of the US population having grown from about $12 \%$ of the population in $2005^{1}$. For engineering colleges and schools that reported Bachelor's (BS) degree data to the American Society for Engineering Education (ASEE), African Americans earned engineering BS degrees at less than one third their representation in the population ${ }^{2}$. In contrast, Hispanic Americans earned engineering BS degrees at about half their representation in the US population and Asian Americans earned engineering degrees at well over twice their representation in the US population. ${ }^{3,4}$ Tremendous changes in Bachelor's (BS), Master's (MS) and Doctoral (PhD) attainment in US engineering schools has taken place in recent years, including changes in the rate of growth of specific disciplines. The goal of this paper is to use ASEE's database to delve deeper into changes in degree attainment for African American women and men within specific engineering disciplines.

\section{Context}

The fraction of engineering BS degrees reported for African Americans declined from $5.1 \%$ in 2004 to $4.3 \%$ in $2013^{2}$, while the number of US BS engineering degrees reported to ASEE increased by about $28 \%{ }^{3}$. Comparing these two years for African American engineering BS degrees shows a 7.6\% percent increase in the number of degrees from 3361 reported in 2004 to 3617 in 2013.

Consistent with prior work that assesses race and gender, ${ }^{5} 2005$ ASEE data shows that the fraction of African American engineering BS degrees reported for females was $32.3 \%$. ${ }^{3,4}$ This female fraction is fifty percent higher than the female fraction of engineering BS degrees overall. By 2013, the female fraction of African American BS degrees had declined to $24.2 \%$. This strong decline in the gender diversity of African American engineering BS degrees is shown in Figure 1, which also shows the initial decline and slight recovery in gender diversity for all engineering BS degrees across the past nine years. The female fraction of engineering BS degrees had reached its highest level in 2002 at $20.9 \%{ }^{6}$

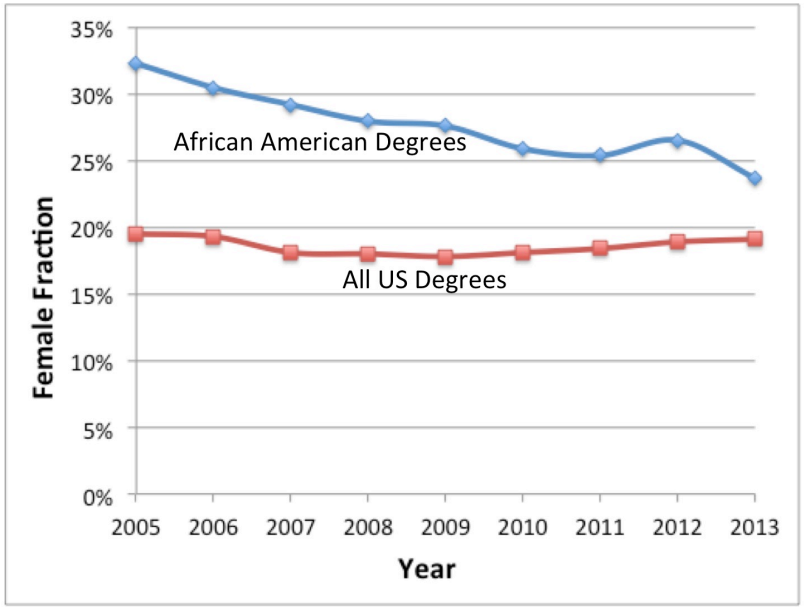

Figure 1 Female fraction of African American and all US BS engineering degrees. ${ }^{2}$ 
African American male recipients of engineering BS degrees grew from 2398 in 2005 to 2742 in 2013, an increase of approximately $14 \% .{ }^{4}$ In contrast, the number of female African American recipients of engineering BS degrees declined 23\%, from 1144 in 2005 to 875 in 2013. Put another way, the fraction of women earning BS engineering degrees who were African American declined from about eight percent in 2005 to just under five percent in 2013.

Figure 2 shows that the number of male African Americans receiving engineering BS degrees has been increasing for about the last five years after several years of little or no change. Simultaneously, the number of female African Americans receiving engineering BS degrees declined fairly strongly from 2005 and has been flat or, at best, slightly improving for the last four years.

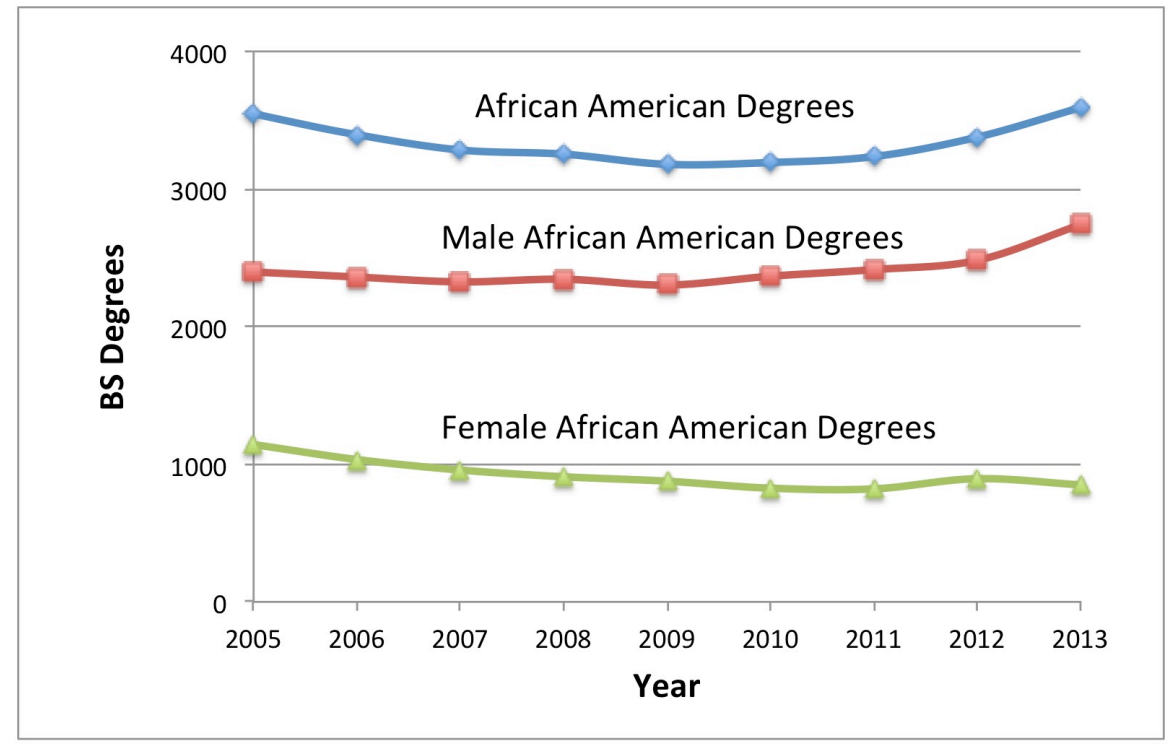

Figure 2 Total, female and male African American Engineering BS degrees. ${ }^{3,4}$

Data for individual engineering colleges shows that North Carolina A\&T and Georgia Tech, the 2013 top producers of African American engineering BS degrees, had substantial decreases in female BS degree recipients from 2005 to 2013. Declines for nearly all of the other top twenty producers of African American engineering BS degrees are shared in Bowman. ${ }^{4}$

Table 1 shows the change in MS degrees for all US engineering programs that have reported data to ASEE with separate columns for all MS degrees and for African American MS degrees. A significantly larger number of female engineering MS degrees in 2013 led to a modest increase of just over one percent in female fraction. The increase in engineering MS degrees for African Americans tracks, within the year-to-year variation, pretty well the growth in engineering MS degrees for all US students. 
Table 1 US Engineering MS Degrees and African American Engineering MS Degrees by Gender $^{2}$

\begin{tabular}{|r|c|c|c|c|c|c|c|c|}
\hline & All US MS & Male US MS & $\begin{array}{c}\text { Female US } \\
\text { MS }\end{array}$ & Female $\%$ & $\begin{array}{c}\text { African Am } \\
\text { MS }\end{array}$ & $\begin{array}{c}\text { African Am } \\
\text { Male MS }\end{array}$ & $\begin{array}{c}\text { African Am } \\
\text { Female MS }\end{array}$ & Female \% \\
\hline 2005 & 40586 & 31385 & 9201 & $22.7 \%$ & 1062 & 734 & 328 & $30.9 \%$ \\
\hline 2013 & 49468 & 37656 & 11812 & $23.9 \%$ & 1270 & 905 & 365 & $28.7 \%$ \\
\hline Change & $21.9 \%$ & $20.0 \%$ & $28.4 \%$ & $1.2 \%$ & $19.6 \%$ & $23.3 \%$ & $11.3 \%$ & $-2.1 \%$ \\
\hline
\end{tabular}

The increase in male African American MS degrees was greater than for female African American MS degrees, resulting in a small reduction in the female fraction for African American MS degrees of $2.1 \%$. The African American fraction of engineering MS degrees was essentially unchanged at around $4.7 \pm 0.3 \%$ from 2005 to 2013 .

Table 2 US Engineering PhD Degrees and African American Engineering PhD Degrees by Gender ${ }^{2}$

\begin{tabular}{|r|c|c|c|c|c|c|c|c|}
\hline & All US PhD & $\begin{array}{c}\text { Male US } \\
\text { PhD }\end{array}$ & $\begin{array}{c}\text { Female US } \\
\text { PhD }\end{array}$ & Female \% & $\begin{array}{c}\text { African Am } \\
\text { PhD }\end{array}$ & $\begin{array}{c}\text { African Am } \\
\text { Male PhD }\end{array}$ & $\begin{array}{c}\text { African Am } \\
\text { Female PhD }\end{array}$ & Female \% \\
\hline 2005 & 7333 & 5988 & 1345 & $18.3 \%$ & 110 & 72 & 38 & $34.5 \%$ \\
\hline 2013 & 10764 & 8350 & 2414 & $22.4 \%$ & 198 & 129 & 69 & $34.8 \%$ \\
\hline Change & $46.8 \%$ & $39.4 \%$ & $79.5 \%$ & $4.1 \%$ & $80.0 \%$ & $79.2 \%$ & $81.6 \%$ & $0.3 \%$ \\
\hline
\end{tabular}

At the doctoral level the increase in degrees was very strong comparing 2013 to 2005. The increase by nearly fifty percent is notable by the very significant difference in growth in degrees for women and men. Female PhDs increased nearly eighty percent while male $\mathrm{PhDs}$ increased about half that amount. This resulted in an increase in the female fraction of US engineering $\mathrm{PhDs}$ from $18.3 \%$ to $22.4 \%$. The increase in engineering $\mathrm{PhDs}$ for African American women and men was substantially higher than US engineering $\mathrm{PhDs}$ overall at about eighty percent. This resulted in little or no change in female fraction for African American $\mathrm{PhD}$ degrees. The fraction of US engineering $\mathrm{PhDs}$ reported for African Americans remains quite low and variable at 3.8 $\pm 0.6 \%$ from 2005 to 2013, with an apparent slightly upward trend.

At the graduate level African American women persist in earning Master's (MS) and Doctoral $(\mathrm{PhD})$ degrees at higher rates than women in general, as shown in Figure 3.

\section{Engineering BS Degrees by Discipline}

Although overall data across engineering colleges and schools is important to document, it is important to remember that engineering is really a collection of disciplines with different histories, areas of emphasis and even cultures. ${ }^{7,8}$ Figure 1 showed that the female fraction of engineering BS degrees declined from $19.5 \%$ in 2005 to a minimum of $17.8 \%$ in 2009 . As of 2013 , the female fraction had recovered slightly to $19.1 \%$. 


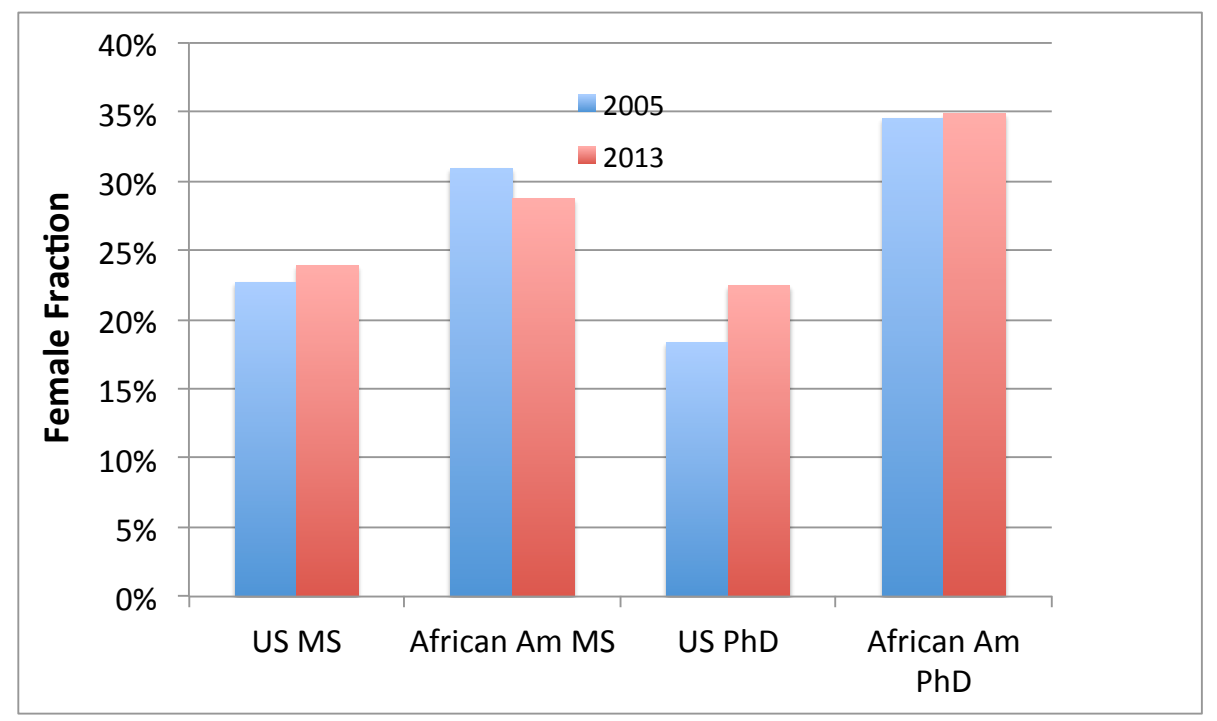

Figure 3 Summary comparison of the female fraction for graduate degrees in 2005 and $2013^{2}$

For the remainder of this paper we will focus on demographic changes for African American women and men in the five largest engineering disciplines, mechanical engineering (ME), electrical and computer engineering (ECE), civil and environmental engineering (CEE), chemical engineering (ChE) and biomedical engineering (BME). Figure 4(a) shows that all of the five largest disciplines had a lower female fraction in 2013 than in 2005 as shown in Table 3.

Table 3 Change in female fraction by engineering

BS discipline 2005 to 2013 (ASEE, 2014)

\begin{tabular}{|r|c|c|}
\hline Discipline & $\begin{array}{c}\text { Female } \\
\text { Fraction }\end{array}$ & $\begin{array}{c}\text { African Am } \\
\text { Female } \\
\text { Fraction }\end{array}$ \\
\hline $\mathrm{ME}$ & $-0.5 \%$ & $-2.6 \%$ \\
\hline $\mathrm{ECE}$ & $-1.2 \%$ & $-8.1 \%$ \\
\hline $\mathrm{CEE}$ & $-0.9 \%$ & $-12.6 \%$ \\
\hline $\mathrm{ChE}$ & $-5.0 \%$ & $-22.8 \%$ \\
\hline $\mathrm{BME}$ & $-3.7 \%$ & $-12.0 \%$ \\
\hline
\end{tabular}

$\mathrm{ChE}$ and BME are well known for having strong gender diversity, but it is apparent that strong growth in degrees overall is being accomplished by faster growth in male degree recipients than for female degree recipients. Figure 4(b) shows that the female fraction for African American engineering BS degrees declined substantially for ECE, CEE, ChE and BME across the past decade. Detail in BS degree changes are described in separate sections showing the changes in BS degrees in more detail along with changes at the MS and $\mathrm{PhD}$ levels. 


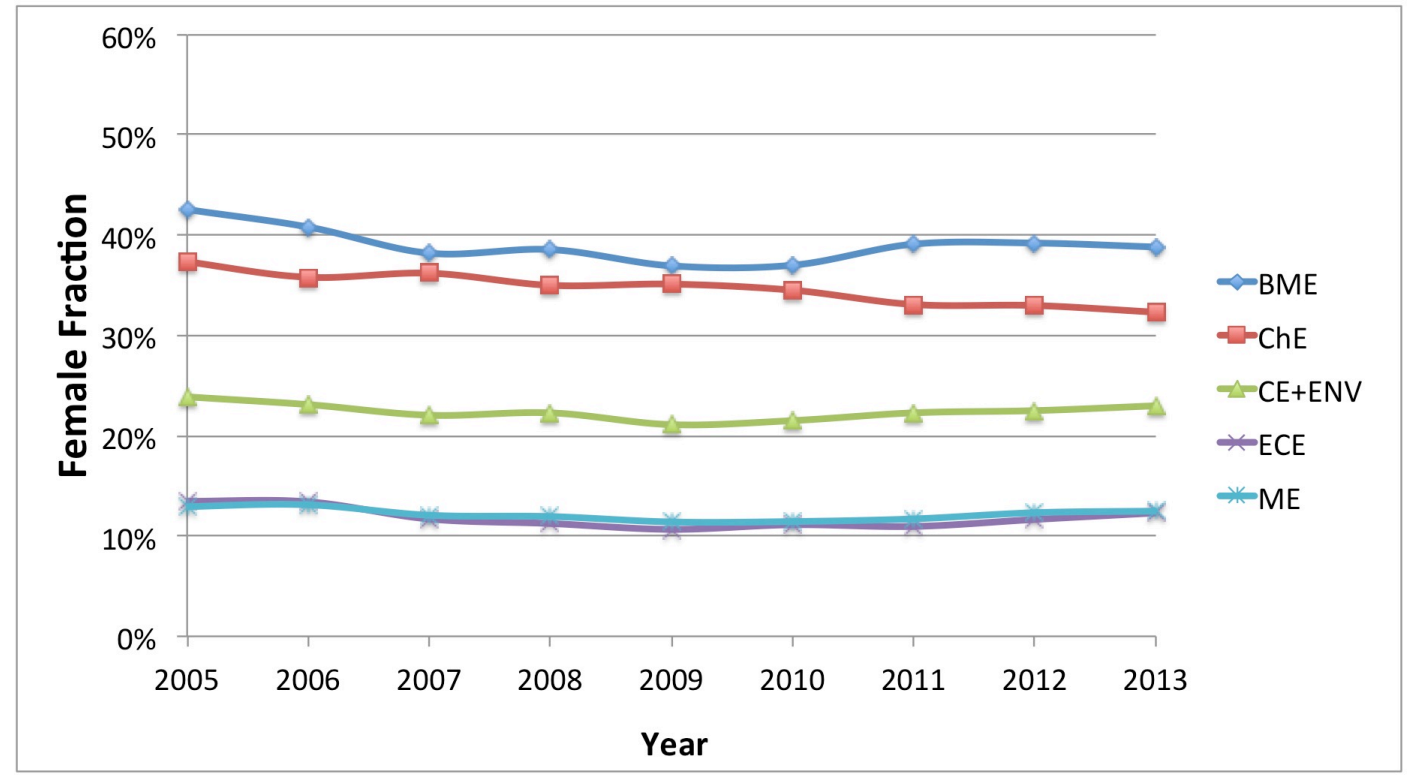

(a) Female fraction for US engineering BS degrees by discipline.

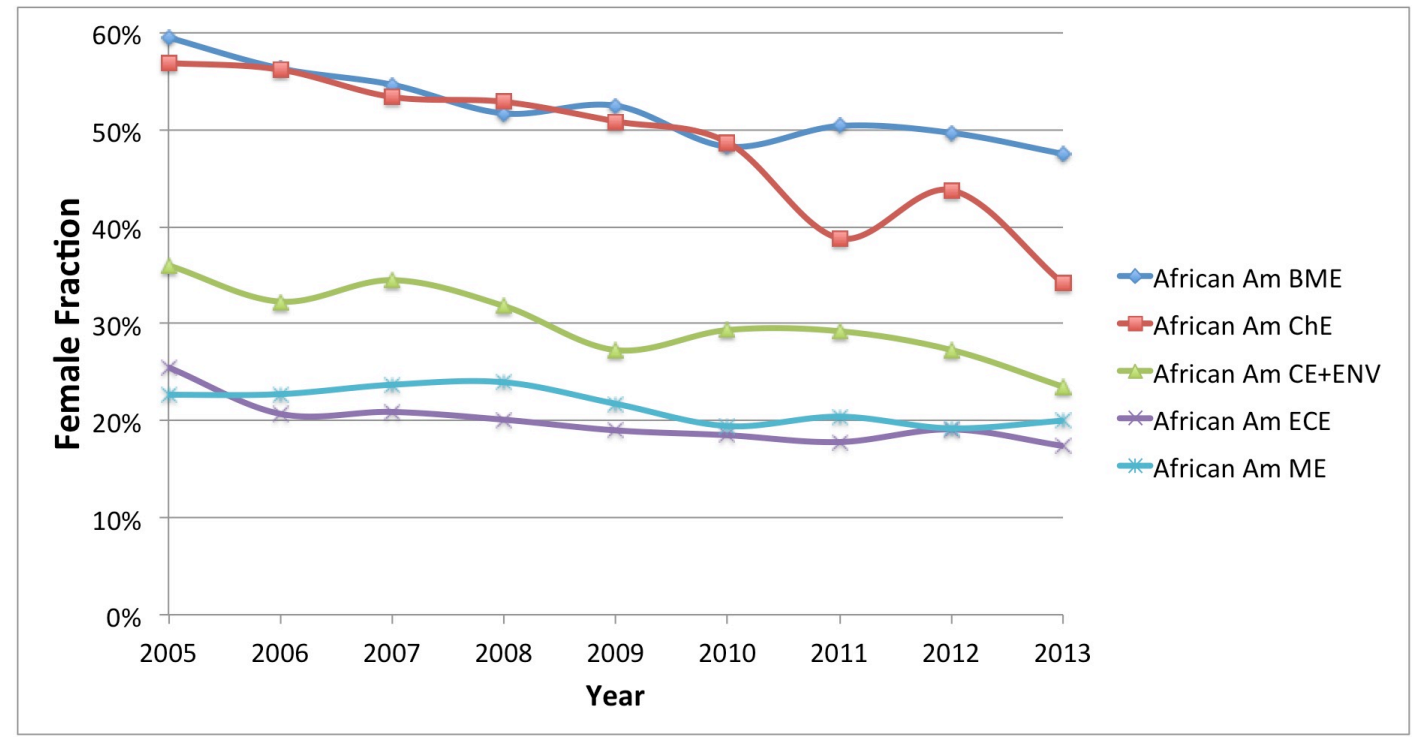

(b) Female fraction of African American BS degrees by discipline.

Figure 4 The female fraction of engineering BS degrees as reported to $\mathrm{ASEE}^{2}$ for (a) all and (b) African Americans. 


\section{Mechanical Engineering}

Total ME BS degree attainment across the past nine years has increased considerably as ME has grown to be the largest undergraduate engineering discipline in the US. ME programs reporting to ASEE at least one BS degree increased from 274 programs in 2005 to 284 programs in 2013 and the number of degrees increased from about 55 to 76 per program. ${ }^{2}$ At the same time, the representation of underrepresented minorities and women has not kept up. ${ }^{9}$ Figure 5 shows via a $\log$ plot that the growth in African American male ME BS degrees lags the growth in ME degrees overall. ME degrees produced in 2013 were about 38\% greater than in 2005 whereas the increase in African American ME BS degrees reported for males was about $26 \%$. And, only $7.5 \%$ more ME BS degrees were reported for African American women in 2013 versus 2005. This led to the decreases for ME shown in Table 3 and Figure 4(b). Altogether, the African American fraction of US ME degree production declined from $4.1 \%$ in 2005 to $3.6 \%$ in 2013.

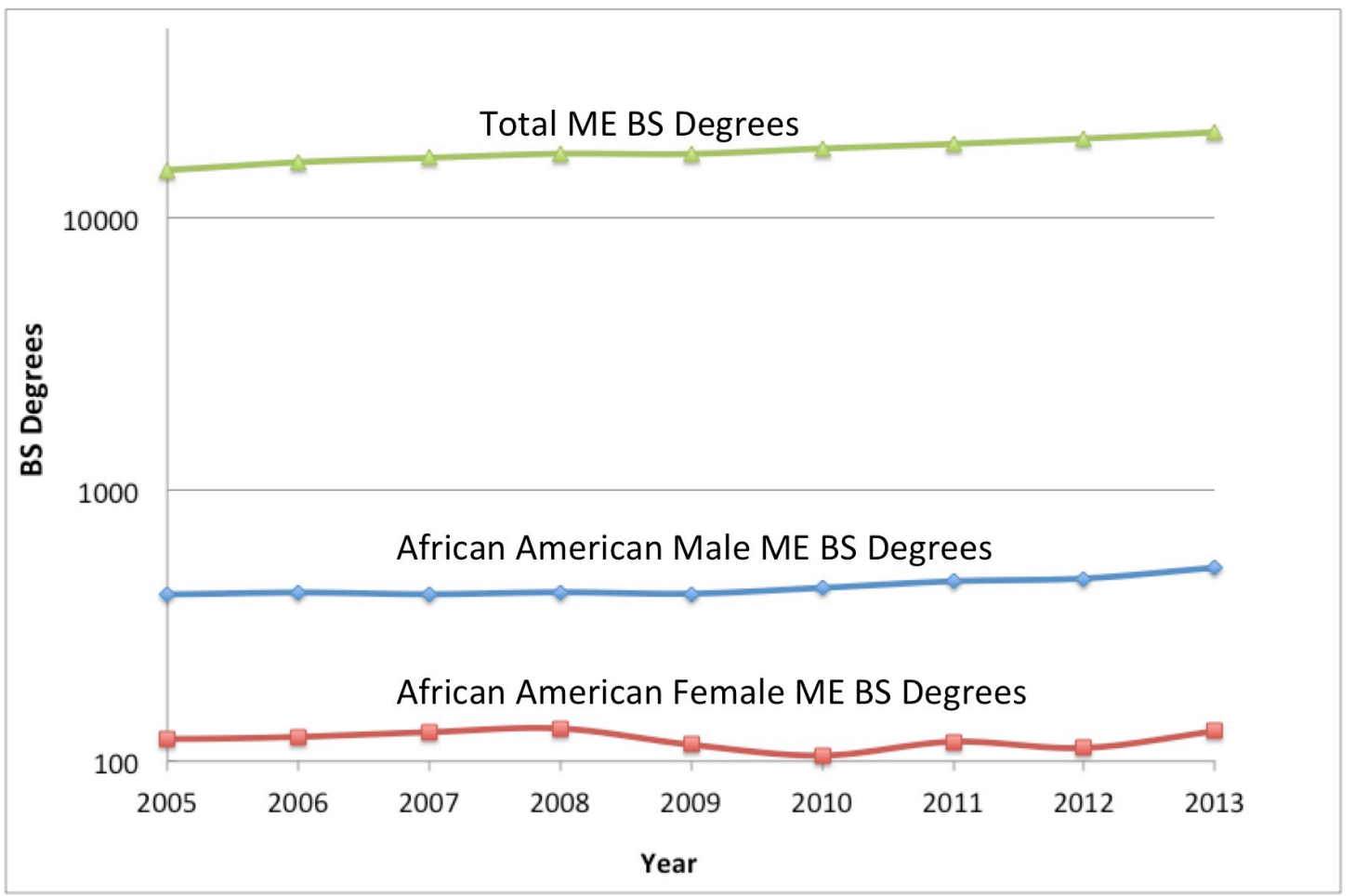

Figure 5 Log plot of total ME BS degrees and female and male African American ME BS degrees. 2,9

Tables 4 and 5 document a comparison between 2005 and 2013 for graduate degrees. ME MS degrees for all groups increased by nearly one third across this period with the rate of increase significantly higher for women than men. But, for male African Americans, the positive increase in ME MS degrees was higher than for females. At the $\mathrm{PhD}$ degree level a very strong increase in degrees of over fifty percent was outpaced by more than a factor of two increase in African American PhD degrees. The gender diversity for PhDs grew significantly leading to a female fraction that is well ahead that 
at the BS degree level. Although the numbers remain small, the increase from zero to six is an overall positive sign. The African American fraction of US domestic $\mathrm{PhD}$ degrees increased from $3.4 \%$ in 2005 to $4.2 \%$ in 2013 .

Table 4 ME MS Degrees ${ }^{2}$

\begin{tabular}{|r|c|c|c|c|c|c|c|c|}
\hline \multicolumn{1}{|l|}{ ME } & All US MS & Male US MS & $\begin{array}{c}\text { Female US } \\
\text { MS }\end{array}$ & Female \% & $\begin{array}{c}\text { African Am } \\
\text { MS }\end{array}$ & $\begin{array}{c}\text { African Am } \\
\text { Male MS }\end{array}$ & $\begin{array}{c}\text { African Am } \\
\text { Female MS }\end{array}$ & Female \% \\
\hline 2005 & 4774 & 4176 & 598 & $12.5 \%$ & 85 & 65 & 20 & $23.5 \%$ \\
\hline 2013 & 6261 & 5368 & 893 & $14.3 \%$ & 110 & 85 & 25 & $22.7 \%$ \\
\hline Change & $31.1 \%$ & $28.5 \%$ & $49.3 \%$ & $1.7 \%$ & $29.4 \%$ & $30.8 \%$ & $25.0 \%$ & $-0.8 \%$ \\
\hline
\end{tabular}

Table $5 \mathrm{ME}$ PhD Degrees ${ }^{2}$

\begin{tabular}{|r|c|c|c|c|c|c|c|c|}
\hline ME & All US PhD & $\begin{array}{c}\text { Male US } \\
\text { PhD }\end{array}$ & $\begin{array}{c}\text { Female US } \\
\text { PhD }\end{array}$ & Female \% & $\begin{array}{c}\text { African Am } \\
\text { PhD }\end{array}$ & $\begin{array}{c}\text { African Am } \\
\text { Male PhD }\end{array}$ & $\begin{array}{c}\text { African Am } \\
\text { Female PhD }\end{array}$ & Female \% \\
\hline 2005 & 965 & 842 & 123 & $12.7 \%$ & 12 & 12 & 0 & $0.0 \%$ \\
\hline 2013 & 1454 & 1238 & 216 & $14.9 \%$ & 28 & 22 & 6 & $21.4 \%$ \\
\hline Change & $50.7 \%$ & $47.0 \%$ & $75.6 \%$ & $2.1 \%$ & $133.3 \%$ & $83.3 \%$ & ---- & $21.4 \%$ \\
\hline
\end{tabular}

\section{Electrical and Computer Engineering}

Electrical Engineering (EE), Computer Engineering (CompE) and Electrical/Computer Engineering (ECompE) are all distinct categories in the ASEE database, but here we are considering all three categories under the heading of ECE. When these disciplines are grouped, since they often represent specific engineering departments, it is well known that between 2005 and 2013 there was a considerable drop in degree production as shown in the log plot of Figure $6 .{ }^{10}$ Table 6 documents the evolution in the number of programs reporting at least one BS degree recipient to ASEE in 2005 and 2013. The number of EE programs remained about the same while the number of ECompE and CompE programs increased.

Table 6 ECE Programs Reporting BS Degree Recipients to ASEE ${ }^{2}$

\begin{tabular}{|c|c|c|c|c|}
\hline Year & EE & ECompE & CompE & Total \\
\hline $\mathbf{2 0 0 5}$ & 255 & 45 & 162 & 462 \\
\hline $\mathbf{2 0 1 3}$ & 254 & 53 & 186 & 493 \\
\hline
\end{tabular}

There were 18 percent fewer BS degrees in the ECE disciplines reported to ASEE in 2013 than in 2005, which resulted in a decrease in BS graduates per degree program from about 45 in 2005 to 33 in 2013. The log plot shows that the decline in African American male ECE BS degrees is less than the decline in ECE degrees overall across the last nine years. But, there is a startling difference by gender. The decrease in the number of African American male BS degrees is about thirteen percent whereas the decrease in African American female BS degrees was nearly fifty percent. This resulted in a decrease in gender diversity among African American BS degrees in ECE from about twenty-six percent to seventeen percent (see Table 3 and Figure 4(b)). The 
contemporaneous change in gender diversity for all ECE BS degrees decreased from about thirteen to twelve percent.

The African American fraction of US ECE BS degree production declined from $7.2 \%$ in 2005 to $6.8 \%$ in 2013. The African American fraction of BS degrees for ECE remains, however, much better than engineering overall, which decreased from $5.3 \%$ to $4.3 \%$ across the same period.

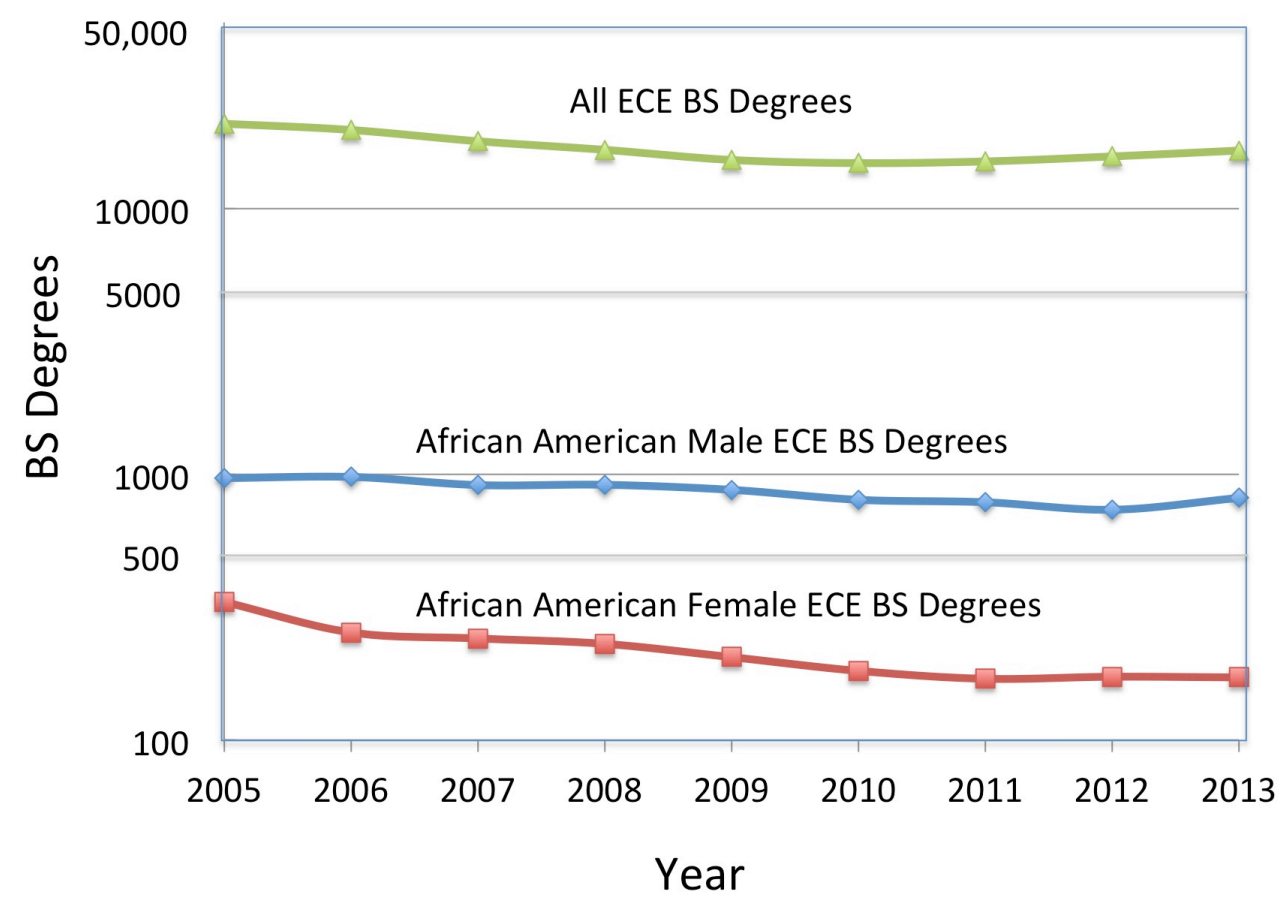

Figure 6 Log plot of ECE BS degrees for all degrees, African American males and African American females. ${ }^{2}$

Tables 7 and 8 show changes in ECE graduate degree demographics since 2005. There was a modest increase in MS degrees and a very strong increase in $\mathrm{PhD}$ degrees. At the MS level, gender diversity declined slightly whereas for African American degrees the number and fraction of female degrees declined dramatically. The growth rate for male MS degrees was strong enough to lead to an increase in the fraction of African American MS degrees. At the $\mathrm{PhD}$ level the number of degrees increased by greater than a third through growth that was much greater for women than men. At the PhD level, however, there was relatively little progress with the total number of African American degrees increasing half as fast as for $\mathrm{PhD}$ degrees overall. All growth in African American PhDs, however, was due to an increase in male $\mathrm{PhDs}$ that made up for a smaller number of female African American PhD recipients. 
Table 7 ECE MS Degrees

\begin{tabular}{|r|c|c|c|c|c|c|c|c|}
\hline \multicolumn{1}{l|}{ ECE } & All US MS & Male US MS & $\begin{array}{c}\text { Female US } \\
\text { MS }\end{array}$ & Female \% & $\begin{array}{c}\text { African Am } \\
\text { MS }\end{array}$ & $\begin{array}{c}\text { African Am } \\
\text { Male MS }\end{array}$ & $\begin{array}{l}\text { African Am } \\
\text { Female MS }\end{array}$ & Female \% \\
\hline 2005 & 11441 & 9081 & 2360 & $20.6 \%$ & 216 & 176 & 40 & $18.5 \%$ \\
\hline 2013 & 11944 & 9608 & 2336 & $19.6 \%$ & 232 & 205 & 27 & $11.6 \%$ \\
\hline Change & $4.4 \%$ & $5.8 \%$ & $-1.0 \%$ & $-1.1 \%$ & $7.4 \%$ & $16.5 \%$ & $-32.5 \%$ & $-6.9 \%$ \\
\hline
\end{tabular}

Table 8 ECE PhD Degrees

\begin{tabular}{|r|c|c|c|c|c|c|c|c|}
\hline ECE & All US PhD & $\begin{array}{c}\text { Male US } \\
\text { PhD }\end{array}$ & $\begin{array}{c}\text { Female US } \\
\text { PhD }\end{array}$ & Female \% & $\begin{array}{c}\text { African Am } \\
\text { PhD }\end{array}$ & $\begin{array}{c}\text { African Am } \\
\text { Male PhD }\end{array}$ & $\begin{array}{c}\text { African Am } \\
\text { Female PhD }\end{array}$ & Female \% \\
\hline 2005 & 1887 & 1635 & 252 & $13.4 \%$ & 28 & 23 & 5 & $17.9 \%$ \\
\hline 2013 & 2579 & 2187 & 392 & $15.2 \%$ & 33 & 29 & 4 & $12.1 \%$ \\
\hline Change & $36.7 \%$ & $33.8 \%$ & $55.6 \%$ & $1.8 \%$ & $17.9 \%$ & $26.1 \%$ & $-20.0 \%$ & $-5.7 \%$ \\
\hline
\end{tabular}

Civil and Environmental Engineering

For this paper, the ASEE categories of civil engineering (CE), civil and environmental engineering (CEnv) and environmental engineering (Env) have been combined into CEE since the last two are small and there is often overlap between the two. Table 9 shows the evolution in the number of programs reporting at least one BS degree recipient to ASEE in 2005 and 2013.

Table 9 CEE Programs Reporting BS Degree Recipients to ASEE

\begin{tabular}{|c|c|c|c|c|}
\hline Year & Civil & Civil/Environmental & Environmental & Total \\
\hline $\mathbf{2 0 0 5}$ & 213 & 7 & 59 & 279 \\
\hline $\mathbf{2 0 1 3}$ & 220 & 21 & 64 & 305 \\
\hline
\end{tabular}

Total CEE BS degree attainment across the past nine years has increased considerably as all degree categories have grown. Figure 7 shows via a log plot that the growth in African American male CEE BS degrees exceed the rate of growth in degrees overall. ${ }^{9}$ CEE degrees produced in 2013 were about $60 \%$ higher than in 2005 whereas the increase in African American ME BS degrees reported for males was about $90 \%$. The increase in CEE BS degrees reported for African American women in 2013 versus 2005 was less than four percent. This resulted in the strong drop in female fraction shown in Table 3 and Figure 4(b). Altogether, the African American fraction of US domestic CEE degree production stayed constant at about $3.4 \%$.

Tables 10 and 11 show changes in CEE graduate degree demographics since 2005. There was a large increase in MS degrees with slightly more growth in degrees reported for women versus men. At the MS level, gender diversity improved slightly overall, but underwent a significant decline in the female fraction of African American MS degrees. This decrease was a result of very strong growth in male African American MS recipients that outpaced MS growth and growth in female African American MS recipients by more than a factor of two. At the PhD level the number of CEE degrees increased by just under a third with growth that was much greater for women versus men. Although the numbers at the $\mathrm{PhD}$ level are small, there were three times as many male African American PhDs 
in 2013 than in 2005 and the number of female PhDs appears to be relatively unchanged. The US domestic fraction of CEE PhDs reported for African Americans has stayed fairly constant at about three percent.

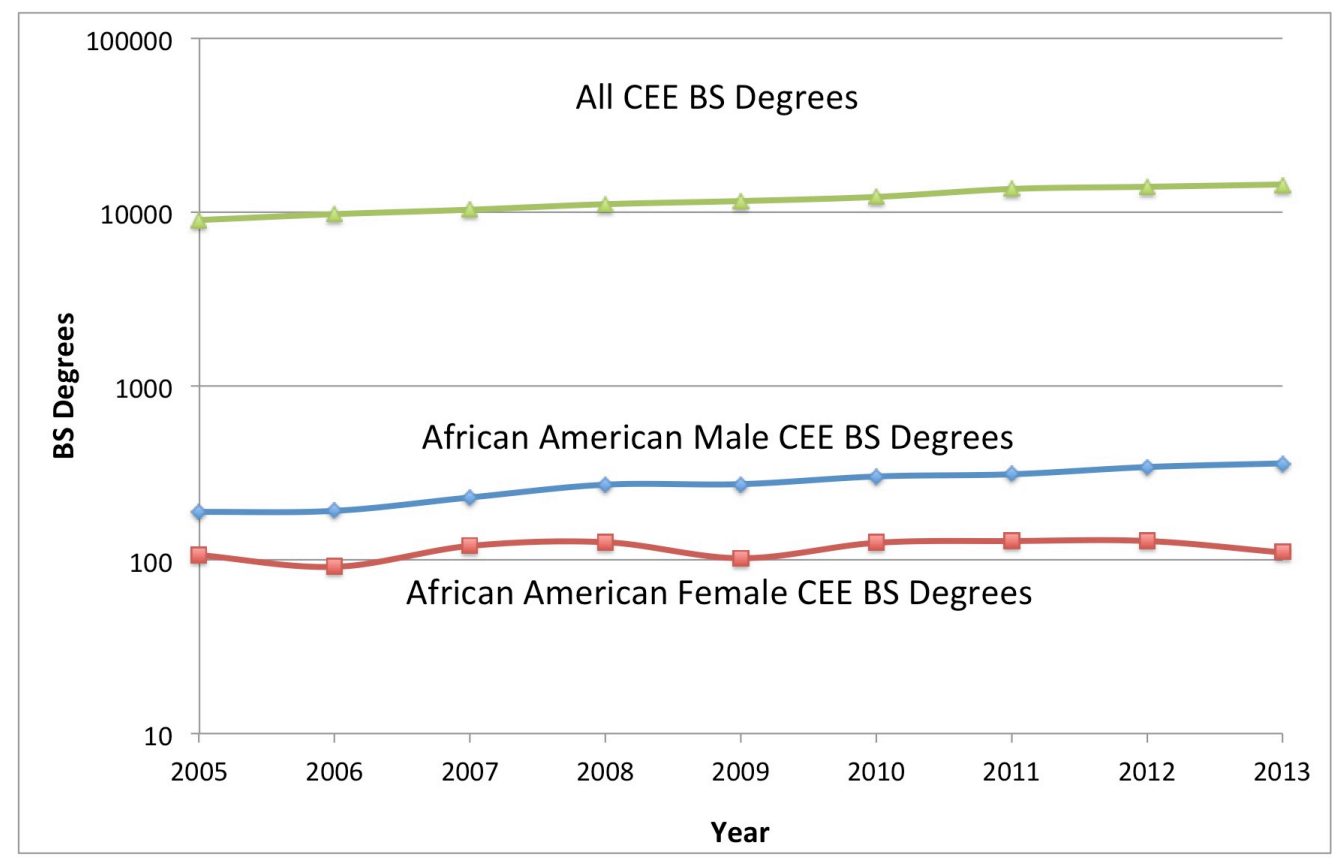

Figure 7 Log plot of total CEE BS degrees and female and male African American CEE BS degrees.

Table 10 CEE MS Degrees

\begin{tabular}{|r|c|c|c|c|c|c|c|c|}
\hline \multicolumn{1}{|l|}{ CEE } & All US MS & Male US MS & $\begin{array}{c}\text { Female US } \\
\text { MS }\end{array}$ & Female \% & $\begin{array}{c}\text { African Am } \\
\text { MS }\end{array}$ & $\begin{array}{c}\text { African Am } \\
\text { Male MS }\end{array}$ & $\begin{array}{c}\text { African Am } \\
\text { Female MS }\end{array}$ & Female \% \\
\hline 2005 & 4592 & 3307 & 1285 & $28.0 \%$ & 106 & 68 & 38 & $35.8 \%$ \\
\hline 2013 & 6337 & 4433 & 1904 & $30.0 \%$ & 177 & 123 & 54 & $30.5 \%$ \\
\hline Change & $38.0 \%$ & $34.0 \%$ & $48.2 \%$ & $2.1 \%$ & $67.0 \%$ & $80.9 \%$ & $42.1 \%$ & $-5.3 \%$ \\
\hline
\end{tabular}

Table 11 CEE PhD Degrees

\begin{tabular}{|r|c|c|c|c|c|c|c|c|}
\hline \multicolumn{1}{|r|}{ CEE } & All US PhD & $\begin{array}{c}\text { Male US } \\
\text { PhD }\end{array}$ & $\begin{array}{c}\text { Female US } \\
\text { PhD }\end{array}$ & Female \% & $\begin{array}{c}\text { African Am } \\
\text { PhD }\end{array}$ & $\begin{array}{c}\text { African Am } \\
\text { Male PhD }\end{array}$ & $\begin{array}{c}\text { African Am } \\
\text { Female PhD }\end{array}$ & Female \% \\
\hline 2005 & 855 & 660 & 195 & $22.8 \%$ & 9 & 3 & 6 & $66.7 \%$ \\
\hline 2013 & 1096 & 776 & 320 & $29.2 \%$ & 14 & 9 & 5 & $35.7 \%$ \\
\hline Change & $28.2 \%$ & $17.6 \%$ & $64.1 \%$ & $6.4 \%$ & $55.6 \%$ & $200.0 \%$ & $-16.7 \%$ & $-31.0 \%$ \\
\hline
\end{tabular}

\section{Chemical Engineering}

ChE BS degree attainment across the past nine years has increased by nearly $70 \%$ with programs reporting to ASEE at least one BS degree increasing from 157 programs in 2005 to 162 programs in 2013 and the number of degrees increased from about 29 to 47 
per program. ${ }^{2}$ Figure 8 shows via a $\log$ plot that the growth in African American male $\mathrm{ChE} \mathrm{BS}$ degrees matched the growth in $\mathrm{ChE}$ degrees overall whereas the number of African American female ChE degrees decreased. ${ }^{11} \mathrm{ChE}$ degrees produced in 2013 were about 70\% greater than in 2005 and the increase in African American ChE BS degrees reported for males was about $69 \%$. There were about one third fewer ChE BS degrees reported for African American women in 2013 than in 2005. Altogether, the African American fraction of US domestic ChE degree production declined from $6.1 \%$ in 2005 to $4.1 \%$ in 2013 .

Tables 12 and 13 show changes in ChE graduate degree demographics since 2005. MS degrees are not common to $\mathrm{ChE}$ where there is often a strong emphasis on doctoral degrees. For $2005137 \mathrm{ChE}$ programs reported at least one MS degree and by 2013 the number of programs reporting had increased to 139. In 2013 the average number of MS degrees earned per ChE program was ten. The fraction of MS degrees earned by women increased by $4.2 \%$ from a growth in female MS degrees that coincided with a drop in male MS degrees. There was a very large decrease in the number of African American MS degrees of nearly one third with the decrease slightly higher for women. At the $\mathrm{PhD}$ level the number of $\mathrm{ChE}$ degrees underwent little change with almost no contemporaneous change in the small number of $\mathrm{PhD}$ degrees earned by male or female African Americans. The US domestic fraction of $\mathrm{PhDs}$ reported for African Americans persists at just under three percent.

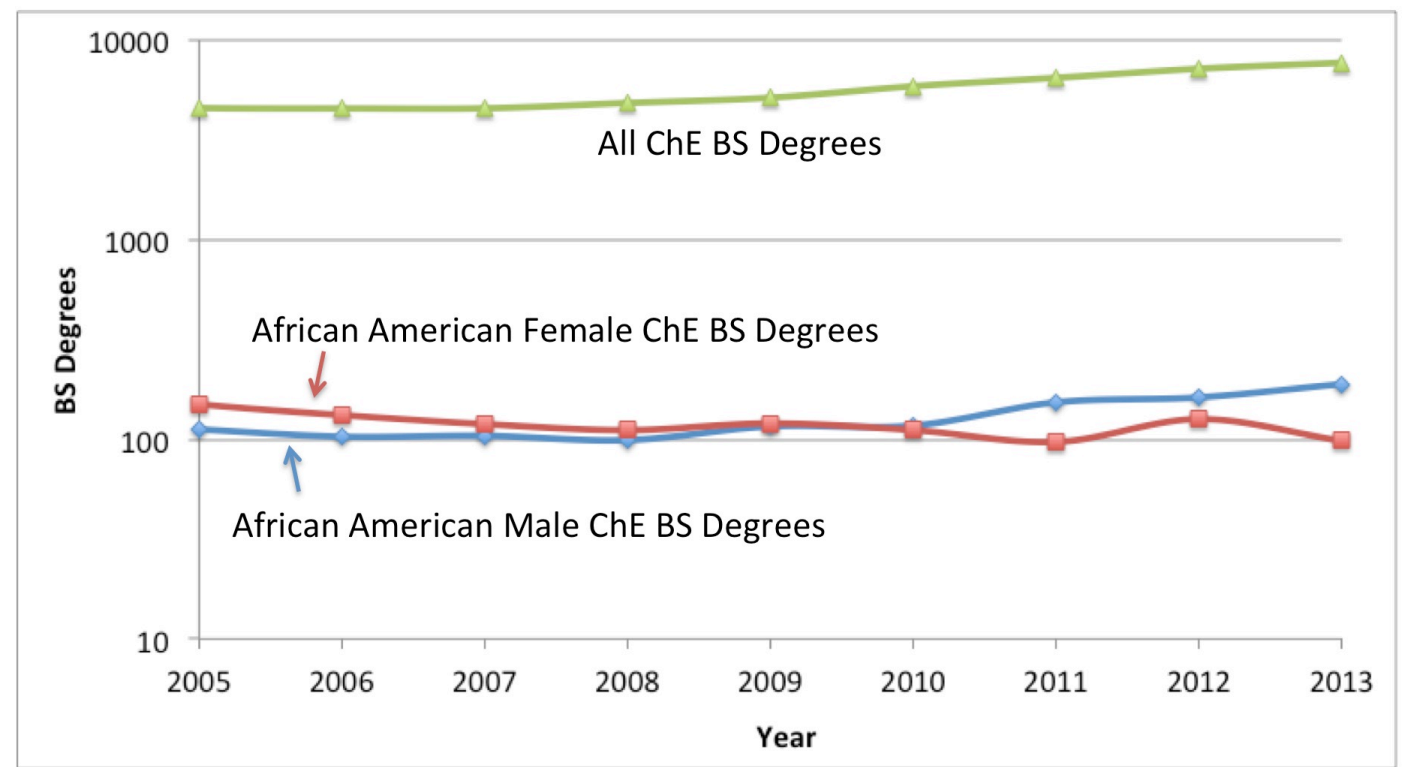

Figure 8 Log plot of total ChE BS degrees and female and male African American ChE BS degrees. ${ }^{2}$ 
Table 12 ChE MS Degrees

\begin{tabular}{|r|c|c|c|c|c|c|c|c|}
\hline \multicolumn{1}{l|}{ ChE } & All US MS & Male US MS & $\begin{array}{c}\text { Female US } \\
\text { MS }\end{array}$ & Female $\%$ & $\begin{array}{c}\text { African Am } \\
\text { MS }\end{array}$ & $\begin{array}{c}\text { African Am } \\
\text { Male MS }\end{array}$ & $\begin{array}{c}\text { African Am Female MS } \\
\text { Female \% }\end{array}$ \\
\hline 2005 & 1405 & 967 & 438 & $31.2 \%$ & 56 & 30 & 26 & $46.4 \%$ \\
\hline 2013 & 1431 & 925 & 506 & $35.4 \%$ & 39 & 22 & 17 & $43.6 \%$ \\
\hline Change & $1.9 \%$ & $-4.3 \%$ & $15.5 \%$ & $4.2 \%$ & $-30.4 \%$ & $-26.7 \%$ & $-34.6 \%$ & $-2.8 \%$ \\
\hline
\end{tabular}

Table $13 \mathrm{ChE}$ PhD Degrees

\begin{tabular}{|r|c|c|c|c|c|c|c|c|}
\hline \multicolumn{1}{l|}{ ChE } & All US PhD & $\begin{array}{c}\text { Male US } \\
\text { PhD }\end{array}$ & $\begin{array}{c}\text { Female US } \\
\text { PhD }\end{array}$ & Female \% & $\begin{array}{c}\text { African Am } \\
\text { PhD }\end{array}$ & $\begin{array}{c}\text { African Am } \\
\text { Male PhD }\end{array}$ & $\begin{array}{c}\text { African Am } \\
\text { Female PhD }\end{array}$ & Female \% \\
\hline 2005 & 822 & 633 & 189 & $23.0 \%$ & 10 & 4 & 6 & $60.0 \%$ \\
\hline 2013 & 858 & 587 & 271 & $31.6 \%$ & 10 & 5 & 5 & $50.0 \%$ \\
\hline Change & $4.4 \%$ & $-7.3 \%$ & $43.4 \%$ & $8.6 \%$ & $0.0 \%$ & $25.0 \%$ & $-16.7 \%$ & $-10.0 \%$ \\
\hline
\end{tabular}

\section{Biomedical Engineering}

BME BS degree attainment across the past nine years has nearly doubled with programs reporting to ASEE at least one BS degree increased from 70 programs in 2005 to 103 programs in 2013 and the number of degrees increased from about 35 to 46 per program. ${ }^{2}$ Figure 9 shows via a log plot the change in total BME BS degrees and BME BS degrees for African American women and men. The growth in African American male BME BS degrees slightly outpaced the growth in BME degrees overall with an increase of $110 \%$ whereas the number of African American female BME degrees increased by only $30 \%$. The female fraction of all BME degrees decreased from $42.5 \%$ to $38.8 \%$ due to a much slower growth in female BS degrees than male BS degrees. The female fraction of African American BS degrees decreased from about $60 \%$ to just under $48 \%$. Altogether, the African American fraction of US domestic BME BS degree production declined from $3.1 \%$ in 2005 to $2.6 \%$ in 2013 .

Tables 12 and 13 show changes in BME graduate degree demographics since 2005. MS degrees are increasingly common to BME with a growth in MS programs from 77 in 2005 to 119 in 2013 and the total number of MS degrees nearly doubling. In 2013 the average number of MS degrees earned per BME program was about 17 having increased from approximately 13 in 2005. The fraction of MS degrees earned by women decreased by $2.9 \%$ due to slower growth in female MS degrees compared to male MS degrees. There was a considerable increase in the number of African American MS degrees earned by men and no change in the number earned by women comparing 2013 to 2005 . At the $\mathrm{PhD}$ level the number of BME degrees nearly tripled with a much higher rate of growth for females versus males. For African Americans there were very strong increases in the number of degrees earned by women and men, which resulted in an increase in the African American fraction of US domestic BME PhDs from 2.9\% to 4.4\%. 


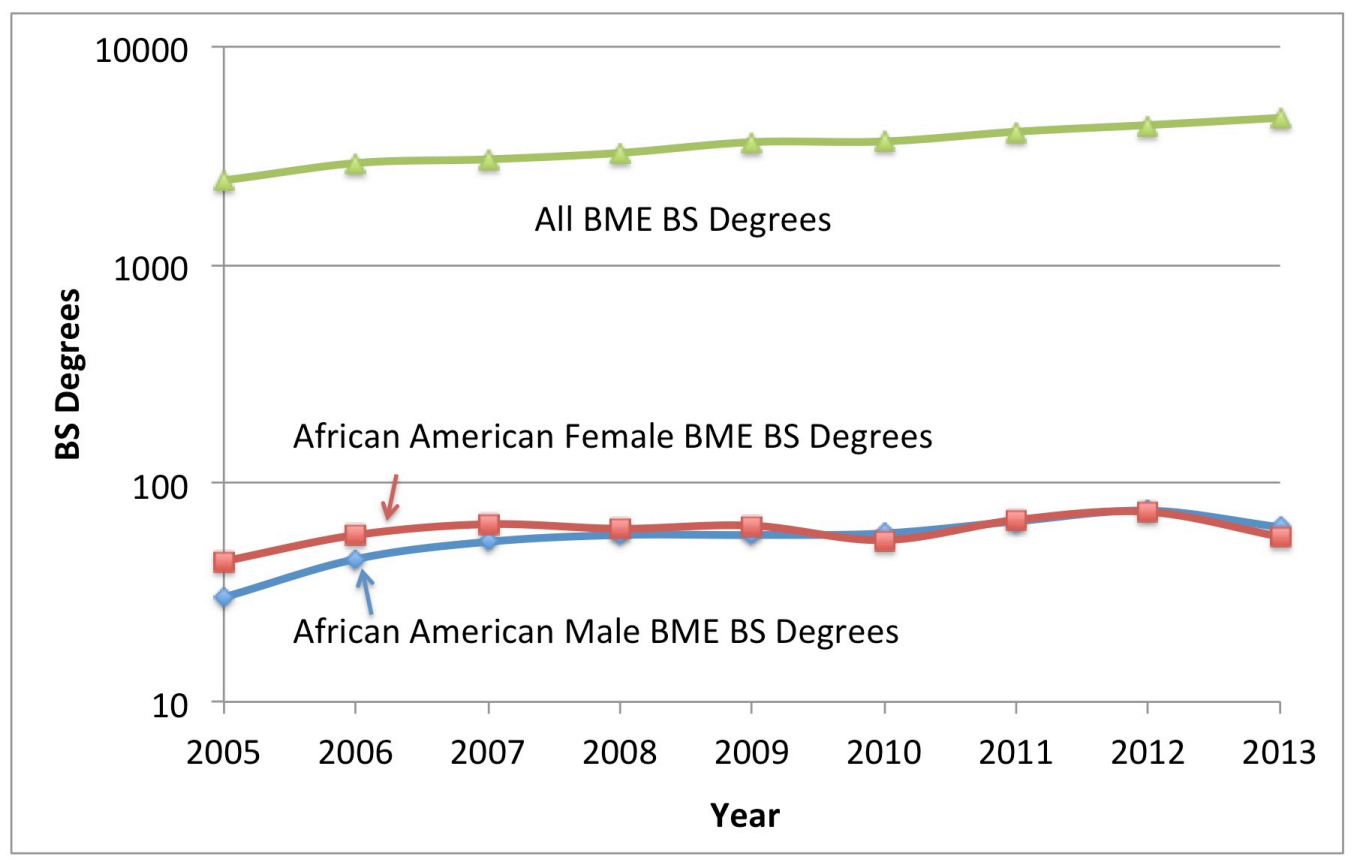

Figure 9 Log plot of total BME BS degrees and female and male African American BME BS degrees.

Table 14 BME MS Degrees

\begin{tabular}{|r|c|c|c|c|c|c|c|c|}
\hline \multicolumn{1}{|l|}{ BME } & All US MS & Male US MS & $\begin{array}{c}\text { Female US } \\
\text { MS }\end{array}$ & Female \% & $\begin{array}{c}\text { African Am } \\
\text { MS }\end{array}$ & $\begin{array}{c}\text { African Am } \\
\text { Male MS }\end{array}$ & $\begin{array}{c}\text { African Am } \\
\text { Female MS }\end{array}$ & Female \% \\
\hline 2005 & 1007 & 567 & 440 & $43.7 \%$ & 25 & 9 & 16 & $64.0 \%$ \\
\hline 2013 & 1997 & 1183 & 814 & $40.8 \%$ & 37 & 21 & 16 & $43.2 \%$ \\
\hline Change & $98.3 \%$ & $108.6 \%$ & $85.0 \%$ & $-2.9 \%$ & $48.0 \%$ & $133.3 \%$ & $0.0 \%$ & $-20.8 \%$ \\
\hline
\end{tabular}

Table 15 BME PhD Degrees

\begin{tabular}{|r|c|c|c|c|c|c|c|c|}
\hline BME & All US PhD & $\begin{array}{c}\text { Male US } \\
\text { PhD }\end{array}$ & $\begin{array}{c}\text { Female US } \\
\text { PhD }\end{array}$ & Female \% & $\begin{array}{c}\text { African Am } \\
\text { PhD }\end{array}$ & $\begin{array}{c}\text { African Am } \\
\text { Male PhD }\end{array}$ & $\begin{array}{c}\text { African Am } \\
\text { Female PhD }\end{array}$ & Female \% \\
\hline 2005 & 332 & 234 & 98 & $29.5 \%$ & 6 & 3 & 3 & $50.0 \%$ \\
\hline 2013 & 920 & 596 & 324 & $35.2 \%$ & 27 & 12 & 15 & $55.6 \%$ \\
\hline Change & $177.1 \%$ & $154.7 \%$ & $230.6 \%$ & $5.7 \%$ & $350.0 \%$ & $300.0 \%$ & $400.0 \%$ & $5.6 \%$ \\
\hline
\end{tabular}

\section{Discussion}

The results shown here demonstrate separation of demographic data for engineering degrees by both gender and race and by discipline and degree level is essential to understand changes that may be occurring within the disciplines of engineering. ${ }^{12}$ Overall, the disturbing decreases in engineering BS degrees and much slower rate of increase in MS degrees for African American women both need attention to understand why this change might be occurring. ${ }^{13}$ We also might reflect on how well we are assessing demographic outcomes such that these changes have gone relatively unnoticed until now. $3,14,15$ 
The relative positive increases in engineering BS degree attainment for male African Americans is a positive outcome and seems to indicate that efforts may be working at least in some disciplines. ${ }^{16,17}$ The smaller decline in African American males for ECE $\mathrm{BS}$ degrees and equal or greater increases in BS degrees in $\mathrm{CEE}, \mathrm{ChE}$ and BME should be assessed to understand how we might attain greater success for these and other disciplines.

At the graduate level, data for all engineering disciplines shows that the female fraction is higher than at the BS degree level. Women increased in MS degree attainment at a somewhat higher rate than for men and increased in $\mathrm{PhD}$ degree attainment at a much higher rate than for men. African American women did not, however, increase in MS degree attainment, but they did increase in $\mathrm{PhD}$ degree attainment at rates comparable to all women and African American men.

Results by discipline were quite mixed. Both ME and BME showed strong increases in the fraction of $\mathrm{PhD}$ degrees reported for African Americans with BME also showing outstanding increases in the female fraction of all and African American doctoral recipients. ECE showed disappointing results for both $\mathrm{MS}$ and $\mathrm{PhD}$ attainment for African American women. And, ChE showed significant decreases in MS degrees for African American women and men.

Recommendations for Research

The annual data presented here strongly suggests that longitudinal studies of the pathways from undergraduate to graduate degrees for African American women and men, and likely all groups, should be investigated within specific degree fields. The changes shown here in degree attainment by gender within a specific race also suggest that there may be advantages if ASEE was able to expand their annual engineering profiles to breakdown gender within specific race and ethnicities.

Also, a combination of qualitative and quantitative studies would be required to reveal the basis for some of the changes observed in the data presented here in order to discover pathways towards better outcomes. By revealing the differences by discipline in more detail than is available elsewhere, it is hoped that steps to address challenges in advancing degrees for African American women and men will be advanced within those disciplines.

\section{References}

1. US Census, http://www.census.gov/

2. ASEE Datamining Tool. (Password Access available for participating institutions) http://edms.asee.org/session/new, Summaries Available as annual ASEE Profiles of Engineering and Engineering Technology Colleges. 
3. Bowman, Keith J., "Disturbing Decline in Engineering Degrees for African American Women" September 21, 2014. https://www.linkedin.com/pulse/article/20140921062338161640750-disturbing-decline-in-engineering-degrees-for-african-american-women

4. Bowman, Keith J., "Texas vs California: Hispanic American Engineers” October 25, 2014 https://www.linkedin.com/pulse/article/20141025070316-161640750-texas-vscalifornia-hispanic-american-engineers

5. McDaniel, Anne, Thomas A. DiPrete, Claudia Buchmann, and Uri Shwed. "The black gender gap in educational attainment: Historical trends and racial comparisons." Demography 48, no. 3 (2011): 889-914.

6. ASEE Profiles of Engineering and Engineering Technology Colleges, ASEE, 2009.

7. Brawner, C. E., Camacho, M. M., Lord, S. M., Long, R. A., \& Ohland, M. W. Women in Industrial Engineering: Stereotypes, persistence, and perspectives. Journal of Engineering Education, 101(2), 288-318, 2012.

8. Bowman, Keith J. "Gender diversity changes in a small engineering discipline: materials science and engineering", Equality, Diversity and Inclusion: An International Journal, 2011, Vol. 30 I: 2, pp.127-144.

9. Bowman, Keith J., "African American Mechanical Engineering Degree Attainment" November 9, 2014, www.linkedin.com/pulse/article/20141109074149-161640750african-american-mechanical-engineering-degrees

10. Bowman, Keith J., "Big Drop in African American Female ECE BS Degrees" November 16, 2014 https://www.linkedin.com/pulse/article/20141117011348161640750-big-drop-in-african-american-female-ece-bs-degrees

11. Bowman, Keith J., "Declining ChE BS Degrees for African American Women" November 28, 2014 https://www.linkedin.com/today/post/article/20141117011348161640750-big-drop-in-african-american-female-ece-bs-degrees

12. Ohland, M. W., Brawner, C. E., Camacho, M. M., Layton, R. A., Long, R. A., Lord, S. M., \& Wasburn, M. H. Race, gender, and measures of success in engineering education. Journal of Engineering Education, 100(2), 225-252, 2011.

13. Chronicle Staff, Chronicle of Higher Education, "Black Women May Face Unique Barriers to Obtaining STEM Degrees," The Ticker, September 24, 2014. http://chronicle.com/blogs/ticker/black-women-may-face-unique-barriers-to-obtainingstem-degrees/86675

14. National Action Council for Minorities in Engineering (NACME), "Underrepresented Minority Women in Engineering,", Research and Policy, Vol 3, Number 3, July. http://www.nacme.org/publications/research_briefs/URMWomeninEngineering.pdf 
15. Whalin, R. W., Pang, Q., \& Jackson, M. Gender and Diversity Trends Of BS Engineering Graduates. 2012 Special Programs Monographs, National Association of African American Studies, 351, 2012. https://www.naaas.org/wpcontent/uploads/2014/09/2012addlmonograph.pdf

16. ASEE Connections, Databyte Section, "Minority Women in Engineering", September, 2014. http://createsend.com/t/y-DE3F7410B158A9A5\#databyte

17. ASEE Prism "Survival Course", May, 2014 http://www.asee-prism.org/survivalcourse/ 